\title{
GENETIC AND CHEMICAL VARIATION OF SERIPHIDIUM QUETTENSE AN ENDEMIC TAXA OF TWO MOUNTAINOUS REGIONS OF QUETTA, PAKISTAN
}

\author{
SAEEd, S. ${ }^{1 *}-$ AhMED, A. ${ }^{1}-$ LAGHARI, S. K. $^{1}-$ Ali, G. M. ${ }^{2}-$ Begum, S. $^{2}$ \\ ${ }^{1}$ Department of Botany, University of Balochistan, Quetta, Pakistan \\ (phone: +92-81-921-1264) \\ ${ }^{2}$ National Institute of Genomics and Advanced Biotechnology (NIGAB), NARC, Islamabad, \\ Pakistan \\ ${ }^{*}$ Corresponding author \\ e-mail: shazia_botany@yahoo.com \\ (Received $12^{\text {th }}$ Nov 2019; accepted $30^{\text {th }}$ Jan 2020)
}

\begin{abstract}
Serriphidium quettense of the Asteraceae family is endemic to Balochistan, Pakistan. It has been used in traditional medicine for treating gastrointestinal diseases; while also having germicidal and antibacterial properties. However, no molecular and chemical characterization was demarcated earlier. Thus this study aimed to depict the genetic variability in two mountainous populations by molecular markers. Genetic variability assessment was carried out by polymorphic bands analysis to generate a dendrogram based on Sequential Agglomerative Hierarchical and Non-overlapping (SAHN) algorithm by Unweighted Pair Group Method of Arithmetic (UPGMA) means by using Numerical Taxonomy and Multivariate Analysis System (NTSYS) Pc version 2.01 for Cluster analysis. Chemical characterization was done by evaluating Total Phenolic Content (TPC) and flavonoids. A total of 68 amplified loci with 30 polymorphic were found with an average of 11.3 and $45 \%$ polymorphism. Cluster dendrogram based on similarity coefficient ranged from 0.285 to 0.785 . Chemical vaiation was assesed by Agglomerative Hierarchical Clustering (AHC) based on dissimilarity matrix as indicated by two main clusters. Cluster 1 was represented by two sub clusters exhibited more chemical variation with in Zargoon population. Overall results obtained exhibited the diverse pattern of genetic and chemical variation. In conclusion, molecular marker profiling together with phytochemical variation of total phenolic and flavonoid content in all accessions of $S$. quettense and impact of ecological diversity on genetic and chemical variation can be used as base line study. Furthermore, implementation of conservation strategies of this endemic medicinal plant is highly recommended.
\end{abstract}

Keywords: cluster analysis, agglomerative hierarchical clustering, morphological, chemical and genetic characterization

\section{Introduction}

S. quettense (Podlech) Ling, Bull. of Asteraceae is an important medicinal plant with different medicinal and ornamental uses. Locally it is known as Jir in Brahvi and Terkhasperah in Pashtu. This species is endemic to Balochistan and utilized abundantly by local communities and grazed by livestock. The genus Seriphidium is a moderate-sized genus comprising of 135 species, distributed in Europe, and temperate Asia, a few species in N. America. Ethno medicinally used for various digestive problems (Anon, 2003; Durrani et al., 2003) also exhibited significant antibacterial activities (Kakar et al. 2012). This shrub provides forage to small ruminants when other range species produce limited dry matter particularly under drought conditions. Likewise, this shrub provides many benefits to humans and animals including feed for livestock and wildlife, erosion control and industrial products. High density of survived seedlings of $S$. quettense was found under plant canopies. Maximum established 
seedlings were observed in the vicinity of adult conspecific plants. High survival rate of $S$. quettense may be due to low autumn precipitation that probably strengthen the seedlings and enable them to survive in winter season (Gul et al., 2007). Morphological markers (similar to leaf shape, plant height, color etc.) are one of the earliest markers utilized in the calculation of genetic variation. Still they are not abundantly unique and informational for the reason that the several chromosome character in the distinctive environments reasons extensive fluctuation of phenotypic qualities in individuals (Shinwari, 2011). Genetic marker is the arrangement of gene or DNA through recognized vicinity upon chromosomes and related to a unique gene or character; it may be defined as a version that can appear because of evolution or alternation of nucleotide in the genomic arrangement that may be discovered (Srivatsava and Nidhi, 2009). Molecular marker based on DNA is helping in development of beneficial plant species. DNA markers are over dependable since the phylogenetic data being exclusive and independent of age for every species, physiologic surroundings and environmental aspect (Kalpana et al., 2004). Based on PCR mostly molecular indicators RAPD is usually a conventional approach in the distinct floras (Mahmood et al., 2011; Kayani et al., 2011). PCR approach is probably the most competitive accessible DNA built techniques used for recording dissimilarities among cultivars inside species (Lakshmikumaran and Bhatia, 1998). Random amplified polymorphic DNA (RAPD) and Inter Simple Sequence Repeat (ISSR) markers were used as combined marker system for genetic variability of wild taxa (Saeed et al., 2017).

In this view, the present study was conducted to assess the genetic variability in two mountainous populations of $S$. quettense from Quetta valley Balochistan, Pakistan represented by six accessions through morphological, molecular and phytochemical profiling.

\section{Materials and Methods}

\section{Site Selection}

Two mountainous ranges of Quetta were selected for plant collection Zarghoon mountain range (3,578 masl) of high hills, steep slopes and narrow valleys and Hazarganji Chiltan National Park mountain range from 1600-3300 $\mathrm{m}$ asl (Figure 1 and Table 1).

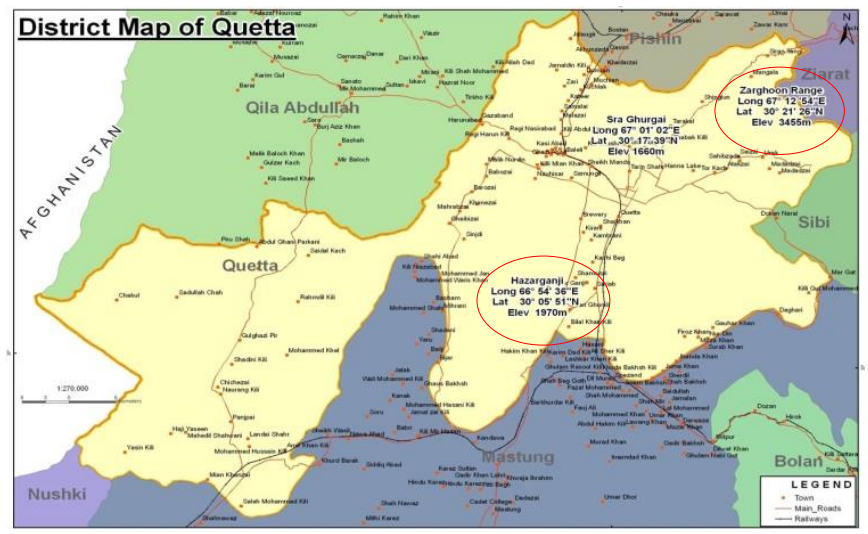

Figure 1. Map of Quetta illustrating two study sites with geographical coordinates from which the examined populations of selected plants were sampled (Source: CAMEOS 2013) 
Table 1. Geographical coordinates of study sites

\begin{tabular}{c|c|c|c|c|c}
\hline S. No. & Sampling sites & Site Code & Latitude (N) & Longitude (E) & Elevation (m) \\
\hline \multirow{3}{*}{ Site 1 } & \multirow{2}{*}{ Zarghoon (ZR) } & B.1 & 30.21 & 67.12 & 2200 \\
& & B.2 & 31.05 & 67.18 & 2830 \\
& & B.3 & 31.22 & 68.01 & 3200 \\
\hline \multirow{3}{*}{ Site 2 } & \multirow{2}{*}{ Hazarganji (HG) } & C.1 & 30.21 & 66.54 & 1700 \\
& & C.2 & 30.07 & 65.55 & 2100 \\
& & C.3 & 30.15 & 66.07 & 2600 \\
\hline
\end{tabular}

\section{Plant Material}

Plants were sampled during (2012-2014) from six different locations from two mountainous ranges and identified. Five replicate samples were collected from each sampling site. The voucher specimens were submitted to herbarium of Botany department, University of Balochistan Quetta for future references. Fresh and young leaves were collected and stored at ultra-low freezer at NIGAB, NARC Islamabad.

\section{DNA Extraction and Purification}

Total genomic DNA was extracted from young and fresh leaves samples of selected plants by CTAB (Cetyl Trimethyl Ammonium Bromide) method as described by Doyle and Doyle (1987) with few modifications (Saeed et al., 2015). The whole procedures including modifications are as follows:

Two to three leaves of plant material were grinded with the help of pestle and mortar, by adding $1 \mathrm{ml}$ of preheated $\left(65^{\circ} \mathrm{C}\right) 2 \mathrm{x}$ CTAB buffer $(100 \mathrm{mM}$ Tris $\mathrm{HCl}(\mathrm{pH} 8.0), 20 \mathrm{~m}$ Methylene Diamine Tetra Acetic acid (EDTA) with $\mathrm{pH} 8.0,1.4 \mathrm{M}$ sodium chloride $(\mathrm{NaCl})$ and $1.5 \%$ mercaptoethanol. The homogenized leaf tissues were transferred to $1.5 \mathrm{ml}$ eppendorf tubes and incubated at $65^{\circ} \mathrm{C}$ for half an hour. An equal volume of chloroform/ isoamyl alcohol was added and the tubes were inverted gently 5-10 times, followed by centrifugation at $10,000 \mathrm{rpm}$ for $10 \mathrm{~min}$. After centrifugation, supernatant was transferred to a new eppendorf tube. Phenol is prepared and used as Phenol:Chloroform :Iso-amyalcohol (P:C:I) $(25: 24: 1, \mathrm{v} / \mathrm{v})$ to the samples to deprotenized the mixture double washed with Chloroform:Isoamyalcohol (C:I) (24:1, v/v). DNA was precipitated by adding an equal volume of $100 \%$ cold isopropanol. The DNA pellets were washed with $70 \%$ cold ethanol. The pellets were air dried and resuspended in the mixture of 40-50 $\mu 10.1 \times$ TE buffer. RNase were incubated at $37^{\circ} \mathrm{C}$ for $30 \mathrm{~min}$ to remove RNA contamination and purified DNA samples were stored at $-20^{\circ} \mathrm{C}$ for further use. The quality of DNA was checked on a $1 \%$ agarose gel prepared in $0.5 \mathrm{x}$ TAE (Tris-acetate-EDTA) buffer. 1\% Agarose gel stained with ethidium bromide was used to observe purified DNA along with DNA standard (50, $100 \mathrm{ng}$ conc.) at 100 to $120 \mathrm{~V}$ for $35 \mathrm{~min}$. The estimation of DNA concentration in a given samples was further checked on Biospec-Nano (230v) at ratio of 260/280 nm and values were recorded. The DNA was diluted by adding $5 \mu \mathrm{l}$ DNA to $95 \mu \mathrm{l} \mathrm{ddH}_{2} \mathrm{O}$ for downstream processes.

\section{Molecular Markers Selection}

For the first time for S.quettense10-mer RAPD (Operon USA) and 18-mer ISSR were purchased from gene link USA (Tables 2 and 3). 
Table 2. List of RAPD markers used for molecular characterization of S. quettense

\begin{tabular}{c|c|c}
\hline S. No. & Primer Name & 'Sequence (5'-3') \\
\hline 1 & OPA-01 & 5'CAGGCCCTTC3', \\
2 & OPA-02 & 5'TGCCGAGCTG3', \\
3 & OPA-03 & 5'AGTCAGCCAC3', \\
4 & OPA-04 & 5'AATCGGGCTG3', \\
5 & OPA-05 & 5'AGGGGTCTTG3' \\
6 & OPA-06 & 5'GGTCCCTGAC3', \\
7 & OPA-07 & 5'GAAACGGGTG3', \\
8 & OPA-08 & 5'GTGACGTAGG3', \\
9 & OPA-09 & 5'GGGTAACGCC3' \\
10 & OPA-10 & 5'GTGATCGCAG3' \\
11 & OPB-01 & 5'GTTTCGCTCC3' \\
12 & OPB-02 & 5'TGATCCCTGG3' \\
13 & OPB-03 & 5'CATCCCCCTG3', \\
14 & OPB-04 & 5'GGACTGGAGT3', \\
15 & OPB-05 & 5'TGCGCCCTTC3' \\
16 & OPB-06 & 5'TGCTCTGCCC3', \\
17 & OPB-07 & 5'GTCCACGCAG3', \\
18 & OPB-08 & 5'TGGGGGACTC3', \\
19 & OPB-09 & 5'CTGCTGGGAC3', \\
20 & OPB-10 &
\end{tabular}

Table 3. List of ISSR primers used for molecular characterization of S. quettense

\begin{tabular}{c|c|c}
\hline S. No. & Name & Sequence (5'-3') \\
\hline 1 & UBC804 & CTCTCTCTCTCTCTCTA \\
2 & UBC806 & CACACACACACACACAT \\
3 & UBC807 & AGAGAGAGAGAGAGAGT \\
4 & UBC808 & AGAGAGAGAGAGAGAGC \\
5 & UBC810 & GAGAGAGAGAGAGAGAT \\
6 & UBC811 & GAGAGAGAGAGAGAGAC \\
7 & UBC851 & GTGTGTGTGTGTGTGTYG \\
8 & UBC852 & TCTCTCTCTCTCTCTCRA \\
9 & UBC853 & TCTCTCTCTCTCTCTCRT \\
10 & UBC854 & TCTCTCTCTCTCTCTCRG \\
\hline
\end{tabular}

\section{PCR Reaction}

The PCR reaction for amplification was carried out in total $20 \mu$ volume. The PCR master mix was prepared that containing, $3 \mathrm{mM} \mathrm{MgCl}$, 1 X PCR buffer, $0.2 \mathrm{mM}$ dNTPs mix, 20 pmol primers, $0.01 \%$ gelatin, 1U/rxn Dream Taq DNA polymerase and $25 \mathrm{ng}$ DNA template DNA. PCR amplification was performed using Applied Biosystems 96 well (USA), thermal cycler. For RAPD primers, PCR was programmed as mentioned below in table with initial denaturation at $94^{\circ} \mathrm{C}$ for $3 \mathrm{~min}$ and then 36 cycles with denaturation at $94^{\circ} \mathrm{C}$ for $1 \mathrm{~min}$, annealing temperature at $36^{\circ} \mathrm{C}$ for $1 \mathrm{~min}$, extension step at $72^{\circ} \mathrm{C}$ for 2 minutes and final extension for 5 minutes at $72^{\circ} \mathrm{C}$. For ISSR primers, PCR was programmed as; initial denaturation at $94^{\circ} \mathrm{C}$ for $3 \mathrm{~min}$ and then 40 cycles with denaturation at $94^{\circ} \mathrm{C}$ for $1 \mathrm{~min}$, annealing temperature $56^{\circ} \mathrm{C}$ for $1 \mathrm{~min}$, extension step at $72^{\circ} \mathrm{C}$ for 2 minutes followed by an additional final extension for 5 minutes at $72^{\circ} \mathrm{C}$ (Abbas et al., 2015). Then amplified products were checked by electrophoresis in $1.8 \%$ agarose gels containing ethidium bromide $(0.5 \mu \mathrm{g} / \mathrm{ml})$ in $1 \mathrm{X}$ TAE buffer. And product 
was visualized by Gel documentation system under UV light and the size of markers were estimated by comparing to the standard ladder (100 bp BIORON $0.2 \mathrm{mg} / \mathrm{ml}$ ) in the gel.

\section{Phytochemical Variation of PSMs}

\section{Flavonoids}

For flavonoids estimation, method described by Ordonez et al. (2006) was used. Take $0.5 \mathrm{ml}$ sample, equal volume of $2 \% \mathrm{AlCl}_{3}$ ethanol solution was added and incubated at room temperature for $1 \mathrm{~h}$. A yellow color indicated the presence of flavonoids. After $1 \mathrm{~h}$, the absorbance was measured at $420 \mathrm{~nm}$ with the help of spectrophotometer. Total flavonoids contents was calculated as quercetin $(\mathrm{mg} / \mathrm{g})$ equivalent equation ( $\mathrm{Y}=0.0255 \mathrm{x}, \mathrm{R}^{2}=0.9812$ ) where $\mathrm{x}$ is the absorbance and $\mathrm{Y}$ is the quercetin equivalent.

\section{Total Phenolic Content (TPC)}

Total Phenolic Contents (TPC) was measured by the method of Slinkard and Singleton (1977). An aliquot of the extract was mixed with $5 \mathrm{ml}$ Folin-Ciocalteu reagent $(\mathrm{FCR})$ reagent (previously diluted with water $1: 10 \mathrm{v} / \mathrm{v}$ ) and $4 \mathrm{ml}$ of sodium carbonate $(7 \%)$. The tubes were vortex for 15 seconds and were allowed to stand for 30 minutes at $40^{\circ} \mathrm{C}$ for color development. Absorbance was then measured at $765 \mathrm{~nm}$. Total phenolic contents were expressed as $\mathrm{mg} / \mathrm{g}$ tannic acid equivalent equation $\left(\mathrm{Y}=0.1216 \mathrm{x}, \mathrm{R}^{2}=0.9365\right)$ where $\mathrm{x}$ is the absorbance and $\mathrm{Y}$ is the quercetin equivalent.

\section{Statistical Analysis}

The amplified bands were scored as 1 (present) and 0 (absent). RAPD and ISSR data were clustered and dendrograms based on similarity matrices were calculated by using Sequential Agglomerative Hierarchical and Non-overlapping (SAHN) algorithm by "Unweighted Pair Group Method with Arithmetic Mean" (UPGMA) through Numerical Taxonomy System (NTSYS) pc 2.10j (Rohlf, 1998). Plant secondary metabolites (PSMs) were analyzed statistically by using XLSTAT version (2007). Clustering were also generated based on dissimilarity matrices by using Agglomerative Hierarchical Clustering (AHC). Data were statistically studied by "Analysis of Variance" (ANOVA) differences in Phytochemical TPC and Flavonoids Significance level $(\mathrm{P}<0.05, \mathrm{P}<0.01$ and $\mathrm{P}<0.001)$ was generated among the samples of different study sites by one way ANOVA.

\section{Results and Discussion}

This is the first comprehensive report of this endemic species $S$. quettense on morphological, chemical and molecular characterization from two mountainous regions of Quetta, Balochistan.

\section{Morphological Diversity}

Morphologically $S$. quettense is a complex species difficult to distinguish from the genus Artemisia life form is Perennial. Height of this shrub may range from 30-40 cm. Habit of shrub is woody below and upright branches are herbaceous aromatic. Stem 
color vary from green to grayish green covered with densely whitish hair sometimes lack hair. Surface also varies from smooth to finely sulcate. Leaves are punctate-glandular, covered by greyish green to whitish hair. Leaf lamina is orbiculate. Upper leaves are sessile. Middle stem leaves are similar to lower but auriculate. Inflorescence based on panicles of 3-4 cm. Capitula numerous, homogamous, sessile, erect. Phyllaries green. Corolla reddish tinged to yellow. Cypsela are $0.8 \mathrm{~mm}$ long mostly brown in colour (Table 4). Present study revealed significant correlation of altitude and morphology of plants. That may be due to the differences of temperature, light intensity, change in soil properties, wind intensity or change in humidity. Earlier reported findings suggest the possibility of adaptation and variation in morphology of the plants due to change in any situations (Hovanden and Schoor, 2003). Plants can also change their morphological characters in harsh climate or weather. They were also capable to alter their characteristics in response to any biotic factors (Stenstrom et al., 2002). Earlier results revealed reduced size of Mimulis primuloide along low altitude that may be due to a higher competition at low altitude. Findings also explored low temperature at high-altitude resulted reduced plant size while increased size at intermediate altitude. Similarly, higher altitude decrease in growth of buds, shorter leaves length and less production of leaves (Tiwari et al., 2013).

Table 4. Morphological Characteristics of S. quettense from Zarghoon and Hazraganji

\begin{tabular}{|c|c|c|c|c|c|c|c|}
\hline Sites & $\begin{array}{c}\text { Stem } \\
\text { colour }\end{array}$ & $\begin{array}{c}\text { Stem } \\
\text { surface }\end{array}$ & $\begin{array}{l}\text { Shoot } \\
\text { length }\end{array}$ & $\begin{array}{l}\text { Leaf } \\
\text { colour }\end{array}$ & \begin{tabular}{|c|} 
Middle \\
leaf length
\end{tabular} & $\begin{array}{c}\text { Leaf } \\
\text { lamina }\end{array}$ & Inflorescence \\
\hline B.1 & Green & Finely sulcate & $25 \mathrm{~cm}$ & Green & $3 \mathrm{~cm}$ & $\begin{array}{l}\text { Orbiculate, } \\
\text { uper sesile }\end{array}$ & Many Capitula. \\
\hline B. 2 & Greish green & Slightly sulcate & $26 \mathrm{~cm}$ & Green & $2.5 \mathrm{~cm}$ & $\begin{array}{l}\text { Orbiculate, } \\
\text { uper sesile }\end{array}$ & Many sessile \\
\hline B. 3 & Green & Slightly sulcate & $30 \mathrm{~cm}$ & Green & $2.9 \mathrm{~cm}$ & $\begin{array}{l}\text { Orbiculate, } \\
\text { uper sesile }\end{array}$ & Many Capitula. \\
\hline C. 1 & Grey & Finely sulcate & $28 \mathrm{~cm}$ & $\begin{array}{l}\text { Silver } \\
\text { green }\end{array}$ & $3 \mathrm{~cm}$ & $\begin{array}{l}\text { Orbiculate, } \\
\text { uper sesile }\end{array}$ & Many sessile \\
\hline C. 2 & Greish green & Smooth & $27 \mathrm{~cm}$ & Green & $3 \mathrm{~cm}$ & $\begin{array}{l}\text { Orbiculate, } \\
\text { uper sesile }\end{array}$ & Many sessile \\
\hline C. 3 & Light green & Sulcate & $28 \mathrm{~cm}$ & $\begin{array}{l}\text { Silver } \\
\text { green }\end{array}$ & $2 \mathrm{~cm}$ & $\begin{array}{l}\text { Orbiculate, to } \\
\text { auriolat }\end{array}$ & Many Capitula. \\
\hline
\end{tabular}

\section{Genetic Diversity}

This is the first comprehensive report on molecular characterization and impact of ecosystem diversity on genetic diversity and chemical variation of $S$. quettense. DNA isolation was carried out without using Liquid Nitrogen. A modified protocol of Doyle and Doyle (1987) was used to extract DNA. This protocol gave a DNA with a sufficient quality to PCR reaction. This plant is also rich in polyphenolic compounds. Out of four tested ISSR and ten-mer RAPD primers on six accessions of two S. quettense populations, 2 ISSR and four RAPD primers exhibited polymorphic bands. (Table 5 shows the banding pattern attained from specific primers). Combined ISSR and RAPD data revealed that total 68 loci are amplified and 30 of them were polymorphic with (44\% polymorphism). Band size for ISSR ranged from 300 to 1500 bp and RAPD primers ranged from 150 to $1000 \mathrm{bp}$ with an average of 11.3 bands per primer (Figure 2). Genetic similarity matrix was produced on the basis of combined ISSR and RAPD markers using genetic similarity coefficient. Results revealed that genetic 
similarity value ranged from 0.285 to 0.785 between populations B.3 and B2. Characterized the closely related population. Mean genetic similarity also calculated as 0.53 the highest degree of genetic similarity occurred between B3 and B2 0.785 of ZR populations depicted low genetic variability within population. In contrast, lowest genetic similarity coefficient of 0.285 was found between B2 (ZR) and C3 (HG) populations, indicating high genetic variability between two mountainous sites. Overall the study revealed that in $S$. quettense genetic variability is $53 \%$ among all comparables (Table 6). Cluster analysis exhibited the UPGMA generated dendrogram by six accessions from two populations (Figure 3) showed exactly two clusters comprising of B2 B3 closely related with in ZR range and C3 cluster HG population further divided into C3, C1, and C2 clusters whereas B1 (ZR) accession also clustered with C2 indicated a different variation pattern. Morphologically $S$. quettense is a complex species difficult to distinguish from the genus Artemisia. Previously Nazar and Mahmood (2011) reported $68 \%$ polymorphism in some species of Artemisia from Rawalakot, Pakistan. Similar type of study was carried out by Hasan et al. (2009) using RAPD markers for evaluating genetic diversity of $A$. capillaris between two populations and has reported low genetic variability within the population. Whereas in present project $44 \%$ polymorphism is observed in $S$. quettense, representing less genetic diversity in isolated populations. This may also be because of over exploitation, uprooting of this significant endemic taxon due to its medicinal value and considered as a good source of fodder for livestock. Additionally, in the vicinity of the study area local communities depend mainly on many wild shrubs including $S$. quettense as a source of fuel for cooking and other purposes.

Table 5. Primers analyses and number of DNA polymorphic bands produced

\begin{tabular}{c|c|c|c|c}
\hline S. No & Primers & TB & NPB & \% PB \\
\hline 1 & OPB-6 & 12 & 6 & 50 \\
2 & OPB-8 & 10 & 4 & 40 \\
3 & OPA-7 & 10 & 4 & 40 \\
4 & OPA-9 & 12 & 4 & 33 \\
5 & ISSR-1 & 12 & 6 & 50 \\
6 & ISSR-2 & 12 & 6 & 50 \\
\hline & TOTAL & 68 & 30 & 44 \\
\hline
\end{tabular}

$\mathrm{T}_{\mathrm{A}}\left({ }^{\circ} \mathrm{C}\right)$ (annealing temperature), TB (Total bands), NPB (Number of polymorphic bands), $\% P B$, percentage of polymorphism

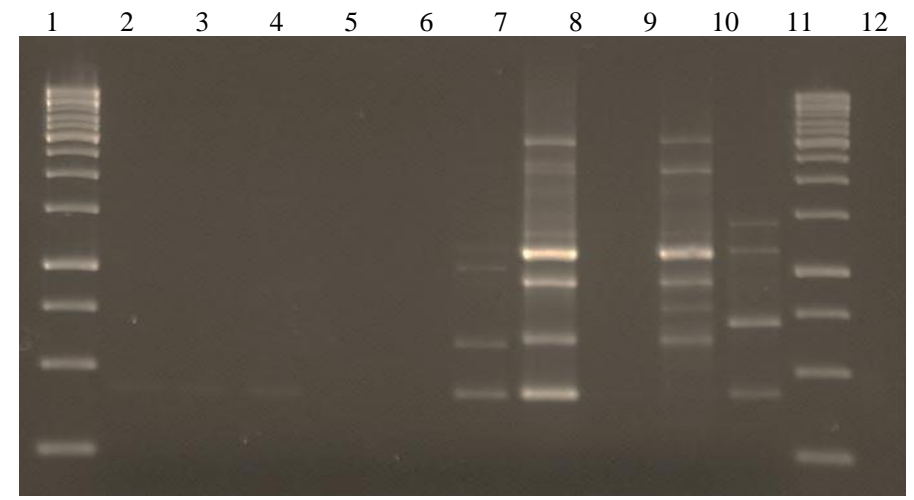

Figure 2. PCR amplification of S. quettense of RAPD OPB-6 population from lane 2-11. With 100 bp marker lane 1 and 12 
Table 6. Genetics similarity matrix of S. quettense based on combined RAPD and ISSR data

\begin{tabular}{l|cccccc}
\hline & B.1 & B.2 & B.3 & C.1 & C.2 & C.3 \\
\hline B.1 & 1 & & & & & \\
B.2 & 0.642 & 1 & & & & \\
B.3 & 0.571 & 0.785 & 1 & & & \\
C.1 & 0.571 & 0.357 & 0.285 & 1 & 1 & \\
C.2 & 0.714 & 0.5 & 0.428 & 0.571 & 1 & 1 \\
C.3 & 0.5 & 0.285 & 0.5 & 0.357 & 0.642 & 1 \\
\hline
\end{tabular}

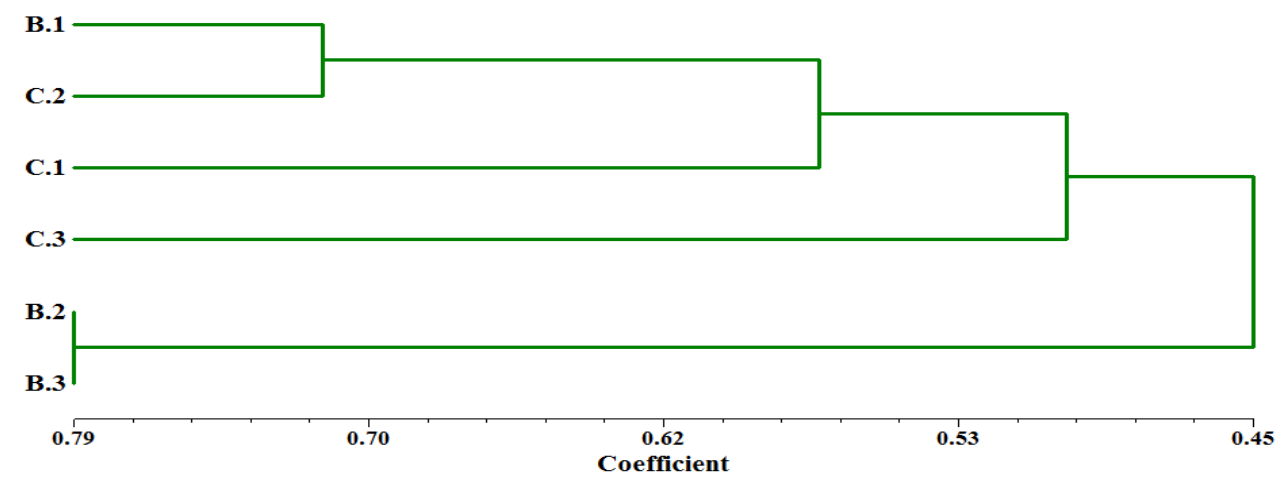

Figure 3. NTSYS- dendrogram of cluster analysis based on data generated from RAPD and ISSR among S. quettense populations (Listed in Table 2)

\section{Chemical Variation}

The results of Chemical variation estimated between and within population. TPC ranged from $42 \mathrm{mg} / \mathrm{g}$ to $47 \mathrm{mg} / \mathrm{g}$ within population B (Zarghoon) and $48 \mathrm{mg} / \mathrm{g}$ to 51 within population $C$ (Hazarganji) Among the population $B$ and $C$ it varies from 42 to $51 \mathrm{mg} / \mathrm{g}$ general linear model ANOVA indicated that the significante diffrence $P=0.03$ at significant level $P<0.05$ (Table 7 , Figure 4). Flavonoids also varies within and among the populations it ranges from $110 \mathrm{mg} / \mathrm{g}$ to $113 \mathrm{mg} / \mathrm{g}$ within population B (Zarghoon) and 92 to $96 \mathrm{mg} / \mathrm{g}$ within population C (Hazarganji). Among the populations it ranges from 92 to $113 \mathrm{mg} / \mathrm{g}$ ANOVA shows it is highly significant $P=0.000$ at significant level $P<0.001$ (Table 8). Chemical vaiation is assesed by Agglomerativ hierarchical clustering (AHC) based on dissimilarity matrix indicated two main clusters. Cluster 1 represented by two sub clusters exhibited more chemical variation with in Zargoon population (Figure 5).

Table 7. Overall Mean $\pm S D$ of TPC and Flavonoid mong different population of S. quettense

\begin{tabular}{c|c|c}
\hline Area Code & Phenolics & Flavonoids \\
\hline B & $44.8 \pm 2.3$ & $112 \pm 1.7$ \\
C & $49.8 \pm 1.4$ & $94.6 \pm 2.1$ \\
\hline
\end{tabular}

Geographical location is the major element that may causes differences in natural climatic condition. Earlier reported research (Malencic et al., 2007) explains with the recorded climatic data that the agricultural practices of various geographical zones are 
incorporating by seasonal and climatic variation. Geographical locations also have an impact on phenolic contents. The phenolic contents are also under the impact of biotic and abiotic stresses. Higher temperature inhibited the expression of flavonoid pathway genes and resulted in lower phenolic accumulation (Yamane et al., 2006; Cohen et al., 2008, 2012). The findings of this project demarcated the Total Phenolic Content (TPC) and flavonoids variation maximum among population supported by similar results that high diversity in quantities of chemical compounds was found among populations (Bottin et al., 2007). On the other hand, the mechanism behind chemical variations is still need to be studied within and among species (Pichersky and Gang, 2000). There are other factors, in addition to genetic and environmental factors that affect the chemical diversity and need to be explored (Kumar et al., 2009). Therefore, future detailed greenhouse studies are suggested to assess correlations between genetic and chemical diversities.

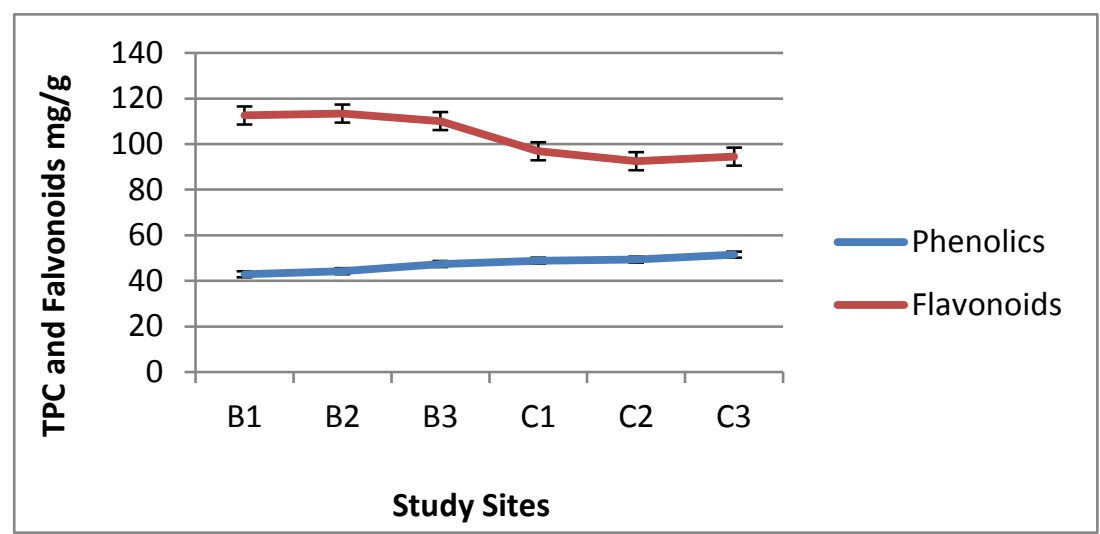

Figure 4. Pehnolics and Flavonoid variation with standard error bars among study sites

Table 8. Analysis of Variance of TPC and Flavonids among different population of S. quettense

\begin{tabular}{c|c|c}
\hline & TPC & Flavonoids \\
\hline F-Value & 10.32 & 117.83 \\
P-Value & 0.03 & 0.000 \\
Significance level & $*$ & $* * *$ \\
\hline
\end{tabular}

Significance level $* * * * * *$ at $\mathrm{p}<0.05, \mathrm{p}<0.01, \mathrm{p}<0.001$ respectively

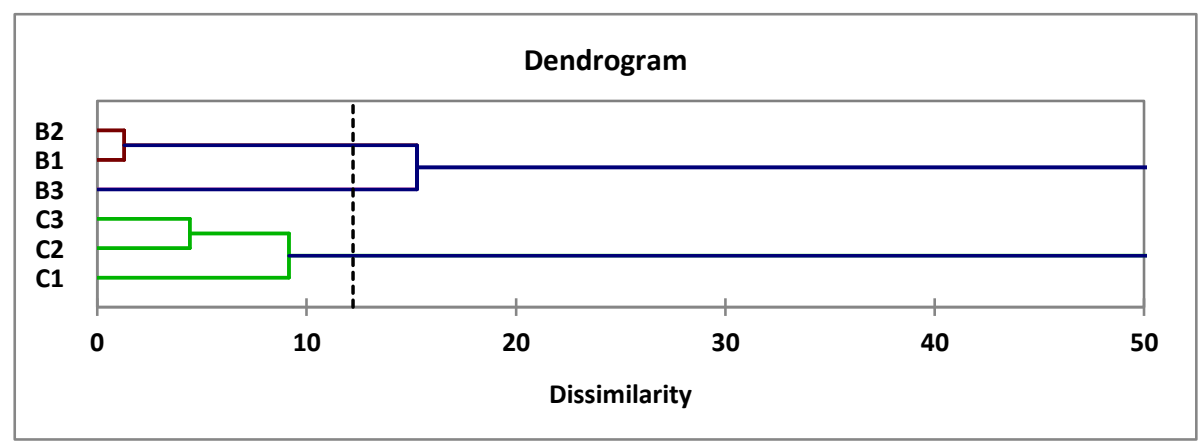

Figure 5. Dendrogram estimating genetic distance among S. quettense populations based on TPC and Flavonoids 


\section{Conclusion}

Based on our findings, it was concluded that there is an impact of ecological consequences on morphological, genetic diversity and phytochemical composition of $S$. quettense. Due to fragmented habitat and anthropogenic effects, diversity within population found to be less than between populations. Though semi-conserved and conserved regions of Zarghoon range and Hazarganji Chiltan National park still retained genetic diversity within populations, however, sustainable management plans are to be implemented. It has also been concluded that the assessment and conservation of genetic diversity through molecular markers is essential that could be used as a key to conserve genetic variability and assess environmental changes on allelic frequency. Furthermore, implementation of conservation strategies for such an important wild endemic taxa is highly recommended.

\section{REFERENCES}

[1] Abbas, G., Hameed, A., Rizwan, M., Ahsan, M., Asghar, M. J., Iqbal, N. (2015): Genetic Confirmation of Mungbean (Vigna radiata) and Mashbean (Vigna mungo) Interspecific Recombinants using Molecular Markers. - Frontiers in Plant Science 6: 1107.

[2] Anonymous. (2003): 1998 District Census Report of Karak. - Publication Census Organization, Statistics Division, Government of Pakistan, Islamabad.

[3] Bottin, L., Isnard, C., Lagrange, A., Bouvet, J. M. (2007): Comparative molecular and phytochemical study of the tree species Santalum austrocaledonicum (Santalaceae) distributed in the New-Caledonian Archipelago. - Chemistry and Biodiversity 4: 15411556.

[4] Cohen, S. D., Tarara, J. M., Kennedy, J. A. (2008): Assessing the impact of temperature on grape phenolic metabolism. - Analytica Chimica Acta 621: 57-67.

[5] Cohen, S. D., Tarara, J. M., Gambetta, G. A., Matthews, M. A., Kennedy, J. A. (2012): Impact of diurnal temperature variation on grape berry development, proanthocyanidin accumulation, and the expression of flavonoid pathway genes. - Journal of Experimental Botany 63: 2655-2665.

[6] Doyle, J. J., Doyle, J. L. (1987): A rapid DNA isolation procedure for small quantities of fresh leaf material. - Phytochemical Bulletin 19(1): 11-15.

[7] Durrani, M. J., Malik, A. M., Hussain, F. (2003): Folk Medicinal plants of Nushki, District Chaghi, Pakistan. - Journal of Science and Technology 27(1-2): 45-52.

[8] Gul, S., Ahmad, S., Achakzai, A. K. K., Islam, M. (2007): Impact of microhabitat on survival of Seriphidium quettense seedlings. - Pak. J. Bot 39(5): 1717-1724.

[9] Hasan, S. M. Z., Shafie, M. S. B., Shah, R. M. (2009): Analysis of Random Amplified polymorphic DNA (RAPD) of Artemisia Capillaris (Worm Wood Capillary) in East Coast of Peninsular Malaysia. - World Applied Sciences Journal 6(7): 976-986.

[10] Hovanden, M. J., Vander, S. J. K. (2003): Nature Vs nurture in the leaf morphology of southern beech, Nothofagus cunninghamii (Nothofagaceae). - New Phytologist 161: 585594.

[11] Kakar, S. A., Tareen, R. B., Kakar, M. A., Jabeen, H., Kakar, S. R., Al-Kahraman, Y. M. S. A., Shafee, M. (2012): Screening of antibacterial activity of four medicinal plants of Balochistan Pakistan. - Pakistan Journal of Botany 44(S): 245-250.

[12] Kalpana, J., Warude, P. C., Bhushan, P. (2004): Molecular markers in herbal drug technology. - Current science 87(2): 159-165.

[13] Kayani, W. K., Majid, S. A., Mahmood, T., Saqlan, S. M. N., Waheed, A. (2011): Effect of temperature Stress on polyphenol oxidase activity in grains of some Wheat cultivars. Pakistan Journal of Botany 43: 1011-1020. 
[14] Kumar, J., Verma, V., Goyal, A., Shahi, A. K., Sparoo, R., Sangwan, R. S., Qazi, G. N. (2009): Genetic diversity analysis in Cymbopogon species using DNA markers. - Plant Omics Journal 2: 20-29.

[15] Lakshmikumaran, M., Bhatia, S. (1998): DNA fingerprinting of medicinal plants. - In: Debry, B. (ed.) Intellectual Property Rights. Rajiv Gandhi Institute for Contemporary studies B.R. Publishing Corporation, Delhi. pp. 293-331.

[16] Mahmood, T., Siddiqua, A., Rasheed, A., Nazar, N. (2011): Evaluation of genetic diversity in different Pakistani wheat land races. - Pakistan Journal of Botany 43(2): 1233-1239.

[17] Malencic, D., Popovic, M., Miladinovic, J. (2007): Phenolic content and antioxidant properties of soyabean (Glycine $\max (\mathrm{L})$ meer.) seeds. - Molecules 12: 576-581.

[18] Nazar, N., Mahmood, T. (2011): Morphological and molecular characterization of selected Artemisia species from Rawalakot, Azad Jammu and Kashmir. - Acta Physiology of Plant 33: 625-633.

[19] Ordonez, A. A. L., Gomez, J. D., Vattuone, M. A., Isla, M. I. (2006): Antioxidant activities of Sechiumedule (Jacq). - Food Chemistry 97: 452-458.

[20] Pichersky, E., Gang, D. R. (2000): Genetics and biochemistry of secondary metabolites in plants: an evolutionary perspective. - Trends in plant Science 5: 439-445.

[21] Rohlf, J. (1998): NTSYSpc numerical taxonomy and multivariate analysis system version 2.0 User Guide F. - Department of Ecology and Evolution State University of New York Stony Brook, NY 11794-5245.

[22] Shinwari, Z. K., Sultan, S., Mehmood, T. (2011): Molecular and Morphological characterization of selected Mentha species. - Pakistan Journal of Botany 43(3): 14331436.

[23] Slinkard, K., Singleton, V. L. (1977): Total phenol analyses: automation and comparison with manual methods. - American Journal for Enology and Viticulture 28: 49-55.

[24] Srivatsava, S., Nidhi, M. (2009): Genetic markers- A cutting edge technology in herbal drug research. - Journal of Chemical and Pharmaceutical Research 1(1): 1-18.

[25] Stenstrom, A., Jonsdottir, I. S., Augner, M. (2002): Genetic and environmental effects on morphology in clonal sedges in the Eurasian arctic. - American Journal of Botany 89: 1410-1421.

[26] Tiwari, S. P., Kumar, P., Yadav, D., Chauhan, D. K. (2013): Comparative morphological, epidermal and anatomical studies of Pinus roxburghii needles at different altitudes in the North-West Indian Himalayas. - Turkish Journal of Botany 37: 65-73.

[27] Williams, J. G. K., Kubelik, A. R. K., Livak, T., Rafalski, J. A., Tingey, S. V. (1990): DNA polymorphisms amplified by arbitrary primers are useful as genetic markers. Nucleic Acids Research 18: 6531-6539.

[28] Yamane, T., Jeong, S. T., Goto-Yamamoto, N., Koshita, Y., Kobayashi, S. (2006): Effects of temperature on anthocyanin biosynthesis in grape berry skins. - American Journal for Enology and Viticulture 57: 54-59. 